\title{
EFEKTIFITAS LARVASIDA AKAR BIDURI (CALOTROPIS GIGANTEA) SEBAGAI ALTERNATIF PEMBASMI JENTIK NYAMUK AEDES AEGYPTI
}

\author{
Desi Yulianti, Yusmidiarti, Agus Widada \\ Politeknik Kesehatan Kementerian Kesehatan Bengkulu, Jurusan Kesehatan Lingkungan \\ Jalan Indragiri Nomor 03 Padang Harapan Bengkulu \\ Jmkbengkulu@gmail.com
}

\begin{abstract}
Biduri plants (Calatropis gigantea) is a wild plant that is very difficult to destroy because of rapid breeding. One of the toxins contained in Biduri is saponin. Therefore Biduri plants very well be used as a repellent for Aedes aegypti mosquito larvae. The research objective was to determine the effectiveness of the roots Biduri larvicides against Aedes aegypti larvae mortality.This research is True Experiments with posttest study design Only Control Group Design. Statistical test results obtained by the one way Anova sig. $=0.000$ so that $\rho<\alpha(0.05)$ means that there is a significant influence on differences in dosing solution Biduri roots are used against Aedes aegypti larvae mortality. Further post hoc test to determine differences in average - average each treatment group using Multiple Comparisons Analysis, LSD (Least Square Difference) obtained sig. $=0.00$ so that $\rho<\alpha(0.05)$ means that there are significant differences in the deadly Aedes aegypti larvae of the four doses were given. Control of Aedes aegypti larvae using Biduri root solution can be done by affixing the root solution with $38 \mathrm{ml}$ of solution Biduri root Biduri every 1 liter of water for 24 hours of exposure.
\end{abstract}

Keywords : root larvasida Biduri, saponins, and Aedes aegypti

\begin{abstract}
Abstrak : Tanaman biduri (Calotropis gigantea) merupakan tanaman liar yang sangat sulit untuk di basmi karena perkembangbiakannya yang cepat. Salah satu racun yang terkandung dalam biduri adalah saponin. Oleh karena itu tanaman biduri sangat baik untuk dimanfaatkan sebagai pembasmi jentik nyamuk Aedes aegypti. Tujuan penelitian adalah untuk mengetahui efektivitas daya larvasida akar biduri terhadap kematian larva Aedes aegypti. Jenis penelitian ini adalah True Eksperimen dengan desain penelitian Posttest Only Control Group Design. Hasil uji statistik dengan one way anova didapatkan nilai sig. $=0,000$ sehingga $\rho<\alpha(0,05)$ artinya ada pengaruh yang signifikan terhadap perbedaan dosis larutan akar biduri yang dipakai terhadap kematian larva Aedes aegypti. Selanjutnya dilakukan uji post hoc untuk mengetahui perbedaan rata - rata setiap kelompok perlakuan dengan menggunakan Analisis Multiple Comparisons, LSD (Least Square Difference) didapatkan sig. $=0,00$ sehingga $\rho<\alpha$ $(0,05)$ berarti ada perbedaan yang signifikan dalam mematikan larva Aedes aegypti diantara ke empat dosis yang diberikan. Pengendalian larva Aedes aegypti dengan menggunakan larutan akar biduri dapat dilakukan dengan cara membubuhkan larutan akar biduri sebanyak $38 \mathrm{ml}$ larutan akar biduri setiap 1 liter air selama 24 jam pemaparan.
\end{abstract}

Kata Kunci : larvasida akar biduri, saponin, dan larva Aedes aegypti

Demam berdarah dengue (DBD) menjadi masalah kesehatan global pada dekade terakhir dengan meningkatnya kasus demam berdarah dengue (DBD) di dunia. World Health Organization (WHO) melaporkan lebih dari 2,5 miliar orang dari dua perlima populasi dunia saat ini berisiko terinfeksi virus dengue dan dapat mengakibatkan kematian dengan cepat serta menimbulkan wabah di seluruh dunia (Riskesdas, 2007).

Jumlah negara yang melaporkan kasus demam berdarah dengue (DBD) dari tahun ke tahun terus bertambah dan tercatat tahun 2007 ada 68 negara yang melaporkan kasus ini. Jumlah tersebut meningkat dari tahun 1999 di mana hanya 29 negara yang melaporkan. Saat ini lebih dari 100 negara di Afrika, Amerika, 
Mediterania Timur, Asia Tenggara, dan Pasifik Barat merupakan wilayah dengan dampak demam berdarah dengue (DBD) serius (Riskesdas, 2007).

Demam berdarah dengue (DBD) pertama kali ditemukan di Filipina pada tahun 1953 dan menyebar ke sejumlah negara. Di Indonesia penyakit ini pertama kali di laporkan pada tahun 1968 di Surabaya dengan jumlah penderita 58 orang, 24 orang diantaranya atau sekitar 41, 3\% berakhir dengan kematian. Dalam waktu singkat demam berdarah dengue (DBD) menyebar di wilayah lain. Kini, seluruh Provinsi di Indonesia sudah terjangkit penyakit demam berdarah dengue (DBD), baik dikota maupun desa terutama yang padat penduduknya, kecuali di wilayah dengan ketinggian lebih dari 1.000 meter di atas permukaan laut (Wahan Komunikasi Lintas Spesialis, 2012).

Kasus penderita demam berdarah dengue (DBD) di Provinsi Bengkulu tahun 2012 juga tercatat sebanyak 409 kasus demam berdarah dengue (DBD) yang terjangkit dan menyebar di 67 Kelurahan Provinsi Bengkulu dan sudah menimbulkan 2 orang korban meninggal dunia. Kasus tersebut meningkat dari tahun 2011 yang hanya 300 kasus (Dinkes Provinsi Bengkulu, 2012).

Dinas Kesehatan Kota Bengkulu mencatat jumlah penderita demam berdarah dengue (DBD) sejak Januari hingga Desember 2012 meningkat sebanyak 66 orang dibandingkan periode yang sama pada tahun 2011. Sejak Januari hingga Desember 2012 jumlah penderita demam berdarah dengue (DBD) mencapai 469 orang jauh lebih meningkat dibandingkan periode yang sama pada tahun 2011 yaitu 403 orang. Ratusan penderita demam berdarah dengue (DBD) tersebut sebanyak 6 orang meninggal dunia, sedangkan pada tahun lalu penderita demam berdarah dengue (DBD) yang meninggal dunia sebanyak 7 orang. Warga kota Bengkulu yang terjangkit penyakit demam berdarah dengue hingga akhir Februari 2012 tercatat 102 orang dan 2 orang diantaranya meninggal dunia (Dinkes Kota Bengkulu, 2012).

Aedes aegypti merupakan vektor utama (95\%) bagi penyebaran penyakit demam berdarah dengue (DBD). Kasus penyebaran dan penularan demam berdarah dengue (DBD) semakin meningkat, disebabkan semakin mudahnya sarana transportasi penduduk, adanya pemukiman baru, kurangnya kepedulian masyarakat terhadap pemberantasan sarang nyamuk, dan terdapatnya vektor nyamuk hampir diseluruh tanah air (Susanto, 2007). Hingga saat ini belum ada obat untuk membasmi virus dan vaksin guna mencegah penyakit demam berdarah dengue (DBD). Cara yang tepat guna untuk menanggulangi penyakit ini secara tuntas adalah memberantas vektor atau nyamuk penular. Sejauh ini cara itu lumayan efektif (Wahana Komunikasi Lintas Spesialis, 2012).

Penggunaan insektisida kimia memang memberikan hasil yang efektif dan optimal, namun banyak dampak negatif yang ditimbulkan baik terhadap organisme hidup maupun lingkungan sekitar. Menurut WHO, kurang lebih 20.000 orang meninggal per tahun akibat keracunan pestisida, selain itu juga menimbulkan dampak fatal, seperti kanker, cacat tubuh, dan kemandulan. Dampak negatif lain diantaranya adalah kematian musuh alami dari organisme pengganggu, kematian yang menguntungkan, mengganggu kualitas dan keseimbangan lingkungan hidup akibat adanya residu serta timbulnya resistensi pada hewan sasaran (WHO, 2004). Banyaknya dampak negatif dari penggunaan insektisida kimia memunculkan penelitian baru dalam pengendalian vektor yang lebih aman, sederhana, dan berwawasan lingkungan. Pengendalian menggunakan insektisida hayati (nabati) adalah salah satunya. Insektisida nabati diartikan sebagai suatu insektisida yang bahan dasarnya berasal dari tumbuhan yang mengandung bahan kimia (bioaktif) yang toksik terhadap serangga namun mudah terurai (biodegradable) di alam sehingga tidak mencemari lingkungan dan relatif aman bagi manusia (Kardinan, 2007).

Insektisida nabati menjadi pilihan karena berbahan dasar tumbuhan, relatif mudah dibuat, ramah lingkungan, tidak mempunyai efek residu serta mempunyai sifat membunuh saat itu residunya cepat hilang (hit and run). Salah satu insektisida nabati yang 
efektif terhadap larva Aedes aegypti adalah Calothropis gigantea atau yang biasa disebut biduri oleh masyarakat Indonesia. Pada umumnya merupakan tanaman yang memiliki khasiat yang sangat banyak (Anonim2, 2009).

Tanaman biduri (Calotropis gigantea) merupakan tanaman liar yang sangat sulit untuk di basmi karena perkembangbiakannya yang cepat. Selain itu, juga mengandung berbagai zat toxic yang biasa disebut zat alelopati. Zat inilah yang melindunginya dari insekta pengganggu. Zat alelopati pada tanaman merupakan bahan yang dapat dimanfaatkan sebagai insektisida alami. Salah satu racun yang terkandung dalam biduri adalah saponin. Oleh karena itu tanaman biduri sangat baik untuk dimanfaatkan sebagai pembasmi jentik nyamuk (Anonim2, 2009). Tanaman biduri (Calotropis gigantea) banyak terdapat di Indonesia salah satunya di Bengkulu yang tumbuh subur di daerah Pantai. Tumbuhan ini mudah didapatkan dan mudah dalam pemanfaatannya. Dari uraian latar belakang diatas, maka tujuan penelitian adalah untuk mengetahui efektivitas daya larvasida akar biduri terhadap kematian larva Aedes aegypti.

\section{BAHAN DAN CARA KERJA}

Penelitian ini merupakan rancangan penelitian eksperimen sungguhan (True Experiment) dengan rancangan posttest dengan kelompok kontrol ("Posttest Only Control Group Design") dengan dianalisis secara deskriptif dan analitik (Notoatmojo, 2010). Adapun desain penelitian yang digunakan adalah 1 kontrol dengan 4 kelompok perlakuan. Penelitian ini akan dilakukan di Laboratorium Poltekkes Kemenkes Bengkulu pada bulan Maret - Mei 2013. Jenis data yang digunakan adalah data primer yang didapat dari jumlah larva yang mati pada pengamatan 1 jam pertama , 2 jam kedua, 3 jam ketiga, dan selama 24 jam. Dihitung larva yang mati pada setiap dosis larutan akar biduri. Analisis yang digunakan adalah analisis univariat, bivariat dengan menggunakan one way anova untuk melihat perbedaan efektifitas larutan akar biduri terhadap kematian larva Aedes aegypti.

\section{HASIL}

\section{Analisis Univariat}

Hasil pengamatan pada uji pendahuluan, menunjukkan bahwa pada pengamatan 1jam pertama, 2jam kedua, 3jam ketiga larva tidak menunjukan adanya kematian, namun larva mulai menunjukan kematian setelah 24 jam perlakuan. Kematian larva $<50 \%$ pada dosis $10 \mathrm{ml}$ dengan konsentrasi larutan sebesar $0,25 \%$ dan $20 \mathrm{ml}$ dengan konsentrasi larutan sebesar 0,5\% dan kematian mencapai $100 \%$ pada dosis $40 \mathrm{ml}$ dengan konsentrasi larutan sebesar 1\%, sedangkan pada kelompok kontrol tidak ada larva yang mati (kematian 0 $\%)$.

Uji pendahuluan dilakukan dengan tujuan untuk mengetahui besar dosis yang mempunyai daya bunuh terhadap larva uji sebesar $50 \%$ kematian larva dari jumlah larva uji pada masing - masing perlakuan sebanyak 20 larva, yang kemudian dipakai sebagai landasan dalam melakukan penelitian lanjutan. Hasil dari uji pendahuluan diperoleh bahwa larutan akar biduri dosis $40 \mathrm{ml}$ sudah mencapai kematian 100\%, sehingga besar dosis larutan akar biduri yang digunakan pada uji lanjutan adalah dosis antara $30 \mathrm{ml}$ sampai $40 \mathrm{ml}$ maka variasinya adalah $32 \mathrm{ml}, 34 \mathrm{ml}$, $36 \mathrm{ml}, 38 \mathrm{ml}$ dan $0 \mathrm{ml}$ sebagai kontrol.

Tabel 2 Kematian larva Aedes aegypti yang diuji dengan larutan akar biduri pemaparan 24 jam

\begin{tabular}{ccccc}
\hline \multirow{2}{*}{ Pengulangan } & \multicolumn{4}{c}{ Dosis dan Konsentrasi Larutan } \\
\cline { 2 - 5 } & $\mathbf{3 2} \mathbf{~ m l}$ & $\mathbf{3 4 m l}$ & $\mathbf{3 6 ~ m l}$ & $\mathbf{3 8 ~ m l}$ \\
$\mathbf{( 0 , 8 \% )}$ & $\mathbf{( 0 , 8 5 \% )}$ & $\mathbf{( 0 , 9 \% )}$ & $\mathbf{( 0 , 9 5 \% )}$ \\
\hline 1 & 17 & 18 & 20 & 20 \\
2 & 18 & 19 & 20 & 20 \\
3 & 17 & 18 & 20 & 20 \\
4 & 17 & 18 & 19 & 20 \\
5 & 17 & 18 & 20 & 20 \\
6 & 17 & 18 & 20 & 20 \\
Jumlah & 103 & 109 & 119 & 120 \\
Rata - rata & 17,17 & 18.17 & 19.83 & 20.00 \\
Persen kematian & $85,85 \%$ & $90,85 \%$ & $99,15 \%$ & $100 \%$ \\
\hline
\end{tabular}

Hasil Pengamatan Pada Uji Lanjutan tabel 1 menunjukkan bahwa kematian $100 \%$ dicapai pada dosis $38 \mathrm{ml}$ dengan konsentrasi larutan sebesar $0,95 \%$, meskipun pada dosis $34 \mathrm{ml}$ dengankonsentrasi larutan sebesar 0,85\% daya bunuhnya sudah mencapai 90,85 $\%$ dan pada dosis $36 \mathrm{ml}$ dengan konsentrasi larutan sebesar $0,9 \%$ daya bunuhnya mencapai 
99,15\%. Uji lanjutan ini dilakukan untuk menentukan dosis efektif dalam mematikan larva Aedes aegypti yaitu dosis yang dapat membunuh $100 \%$ kematian dari 20 larva yang diujikan.

\section{Analisis Bivariat}

Tabel 3 menunjukkan hasil uji statistik one way anova yang didapatkan nilai $\rho$ value $=$ 0,000 sehingga $\rho$ value $<\alpha(0,05)$ berarti ada pengaruh yang signifikan terhadap variasi dosis larutan akar biduri yang dipakai terhadap kematian larva Aedes aegypti, maka uji lanjut (Post Hoc Test) harus dilakukan, karena hasil uji Anova menunjukan adanya pengaruh yang signifikan, maka uji selanjutnya adalah melihat perbedaan antar kelompok kontrol dengan kelompok perlakuan, dengan menggunakan Analisis Multiple Comparisons, LSD (Least Square Difference). Hasil uji LSD yang diperoleh, dapat dilihat pada tabel 4.8.

Tabel 3 Hasil Uji One Way Anova

\begin{tabular}{ccccc}
\hline Variabel & Mean & SD & $\mathbf{9 5 \%}$ CI & p Value \\
\hline dosis 32 & 17.17 & .408 & $16.74-20.26$ & .000 \\
dosis 34 & 18.17 & .408 & $17.60-20.00$ & \\
dosis 36 & 19.83 & .408 & $17.74-20.00$ & \\
dosis 38 & 20.00 & .000 & $18.60-18.26$ & \\
Total & 18.79 & 1.250 & $19.40-19.32$ & \\
\hline
\end{tabular}

Tabel 4 menunjukkan hasil uji $L S D$ bahwa terdapat perbedaan yang bermakna pada hampir semua dosis karena sig. 0,000 ( $\rho$ $<0,05)$ kecuali pada dosis $36 \mathrm{ml}$ dengan konsentrasi larutan sebesar 0,9\% dan $38 \mathrm{ml}$ dengan konsentrasi larutan sebesar 0,95\% yang tidak terdapat perbedaan yang bermakna karena sig. 0,424 $(\rho>0,05)$. Dosis yang paling efektif yaitu $38 \mathrm{ml}$ dengan rata-rata kematian 20 larva (100\% kematian), dan ratarata terendah kematian pada dosis $10 \mathrm{ml}$ dengan konsentrasi larutan sebesar $0,25 \%$ yaitu sebesar 5,33 (26,65\%).

Perbedaan kematian larva nyamuk Aedes aegypti pada berbagai dosis yang diberikan pada penelitian ini terjadi karena jumlah larutan akar biduri yang dibubuhkan oleh larva Aedes aegypti juga berbeda, tergantung pada dosis larutan yang diberi-kan. Dengan demikian dapat disimpulkan bahwa dengan pemberian dosis yang semakin tinggi, maka jumlah kematian larva Aedes aegypti semakin meningkat.

Tabel 4 Hasil uji Multiple Comparisons (LSD)

\begin{tabular}{cccc}
\hline \multicolumn{2}{c}{ perlakuan } & $\begin{array}{c}\text { Mean } \\
\text { Difference }\end{array}$ & Sig. \\
\hline dosis 32 ml & dosis 34 ml & $1.000^{*}$ & .000 \\
& dosis 36 ml & $2.667^{*}$ & .000 \\
& dosis $38 \mathrm{ml}$ & $2.833^{*}$ & .000 \\
dosis 34 ml & dosis 36 ml & $1.667^{*}$ & .000 \\
& dosis 38 ml & $1.833^{*}$ & .000 \\
dosis 36 ml & dosis 38 ml & .167 & .424 \\
\hline
\end{tabular}

\section{PEMBAHASAN}

Pengukuran suhu pada penelitian adalah $26{ }^{0} \mathrm{C}$ baik pada kelompok kontrrol maupun pada perlakuan sedangkan suhu optimal untuk perkembangan larva Aedes aegypti adalah 25$29^{\circ} \mathrm{C}$ dan pertumbuhan nyamuk akan berhenti sama sekali bila suhu kurang dari $10^{\circ} \mathrm{C}$ atau lebih dari $40^{\circ} \mathrm{C}$, berarti suhu pada saat penelitian memenuhi suhu optimal untuk pertumbuhan larva. Suhu larutan merupakan salah satu faktor yang dapat mempengaruhi perkembangan dan kehidupan larva Aedes aegypti, Larva memi-liki kisaran suhu tertentu dimana dia dapat hidup. Di luar kisaran suhu tersebut, serang-ga akan mati kedinginan atau kepanasan. Pada umumnya kisaran suhu yang efektif adalah suhu minimum $15^{\circ} \mathrm{C}$, suhu optimum $25^{\circ} \mathrm{C}$, dan suhu maksimum $45^{\circ} \mathrm{C}$ (Jumar, 2000).

Kelompok kontrol memiliki pH sebe-sar 7 (pH netral), yang berarti kondisi $\mathrm{pH}$ air masih dalam kisaran $\mathrm{pH}$ normal. Sedangkan besarnya $\mathrm{pH}$ larutan pada kelompok perlakuan berkisar antara 6,0- 6,9 memenuhi pH optimal untuk perkembangan larva. Hal ini menunjukkan bahwa kenaikan dosis mengakibatkan $\mathrm{pH}$ larutan semakin menurun (cenderung ke arah asam). Namun, penurunan ini tidak begitu mempengaruhi kehidupan larva, karena larva Aedes aegypti masih dapat berkembang dan hidup pada kisaran $\mathrm{pH}$ antara 4-11 (Clark, 2004). Sedangkan berdasarkan penelitian Hidaya, (1997) larva dapat hidup pada air dengan $\mathrm{pH}$ antara 5,88,6. Jadi, pH larutan pada peneli-tian ini masih memenuhi kisaran normal untuk pertumbuhan larva. Pada dosis terendah adalah dosis $10 \mathrm{ml}$ mempunyai $\mathrm{pH}$ 6,0, sedangkan pada dosis tertinggi $40 \mathrm{ml}$ mempunyai $\mathrm{pH} \mathrm{6,9.}$ 
Dosis yang paling efektif untuk membunuh larva Aedes aegypti yaitu $38 \mathrm{ml}$ dengan konsntrasi larutan sebesar 9.500 ppm karena dapat mematikan $100 \%$ kematian larva dari 20 larva yang diujikan setelah pemaparan 24 jam. Perhitungan waktu dimulai setelah pemasukkan larva ke dalam mangkok. Pengamatan alur hidup yaitu larva uji diberikan larutan, larva mampu bertahan hidup pada jangka waktu tertentu namun tidak dapat mencapai tahap selanjutnya. Efek kematian dimaksud yaitu larva uji mengalami kematian akibat adanya aktivitas larutan larvasida yang diberikan. Paparan larva Aedes aegypti terhadap larutan yang mengandung saponin dalam waktu yang lama dan dosis yang besar dapat mening-katkan efek toksisitasnya.

Larutan akar biduri diujikan terhadap larva nyamuk Aedes aegypti instar-IV. Instar merupakan tahapan perkembangan dalam salah satu fase metamorfhosis nyamuk (Andriani 2008). Pemilihan larva instar-IV sebagai hewan uji karena instar-IV merupakan fase akhir pada larva nyamuk Aedes aegypti sehingga memiliki daya tahan paling tinggi dibandingkan instar I, II, atau III. Selain itu, ukuran larva nyamuk Aedes aegypti instarIV lebih besar sehingga lebih mudah dalam perhitungan kematian. Per-kembangan larva nyamuk Aedes aegypti ada 4 tahapan perkembangan yaitu instar I, II, III, dan IV. Perubahan instar tersebut disebabkan larva mengalami pengelupasan kulit atau bisa disebut moulting. Perkembangan dari instar I ke instar II berlangsung dalam waktu 2-3 hari, kemudian dari instar II ke instar III dalam waktu 2 hari dan perubahan dari instar III ke instar IV dalam waktu 1 hari. Kemudian menjadi pupa. Ciri-ciri larva instar IV yaitu telah lengkap struktur anatominya, dan jelas tubuhnya dapat dibagi menjadi bagian kepala (chepal), dada (thorax), dan perut (abdomen). Pada bagian kepala terdapat sepasang mata majemuk, sepasang antena tanpa duri-duri dan alat-alat mulut tipe pengunyah (chewing).Lama perkembangan tergantung dari suhu, keterse-diaan makanan dan kepadatan larva pada sarang perindukan. Jentik Aedes aegypti berukuran panjang 0,5-1 $\mathrm{cm}$, selalu bergerak aktif di dalam air, gerakanya berulang-ulang dari bawah ke atas permukaan air untuk bernafas, kemudian turun kembali ke bawah dan seterusnya. Saponin mengakibatkan ukuran larva yang mati lebih panjang sekitar 1-2 $\mathrm{mm}$ dibandingkan sebelum perlakuan.

Senyawa saponin yaitu kardiak gliko-sid (kardinolid) yang dapat membunuh larva nyamuk Aedes aegypti instar IV, senyawa tersebut bekerja sebagai racun pernafasan, setelah racun masuk melalui mulut larva, maka racun menganggu saraf, saluran nafas, dan pencernaan larva. Senyawa saponin merusak membran pada kulit larva dan menyebabkan larva mati. Hal ini menyebabkan larva gagal mendapat stimulus rasa sehingga tidak mampu mengenali makanannya. Saponin adalah suatu glikosida yang ada pada berbagai macam tanaman. Toksisi-tasnya disebabkan karena dapat merendah-kan tegangan permukaan (surface tension) namun, saponin tidak toksik untuk manusia bila dikonsumsi (Nio, 1989).

Saponin dapat merusak membran sel dan mengganggu proses metabolisme serangga, Saponin merupakan senyawa metabolit sekunder yang dihasilkan spesies tanaman yang berbeda, terutama tanaman dikotil dan berperan sebagai bagian dari sistem pertahanan tanaman dan termasuk ke dalam kelompok besar molekul pelindung tanaman. Saponin diketahui mempunyai efek anti jamur dan anti serangga (Suparjo, 2008). Kandungan saponin bekerja sebagai racun perut dan racun pernafasan dimana zat tersebut dapat masuk ke tubuh larva melalui mulut larva (termakan larva) kemudian meracuni larva tersebut. Selain itu sebagai racun pernafasan, zat dalam larutan akar biduri tersebut dapat meracuni larva melalui saluran pernafasan larva yang ada di permukaan tubuh larva yang kemudian masuk ke dalam tubuh larva (Aminah, 2001).

Kandungan saponin yang diduga mengandung hormone steroid yang berpengaruh dalam pertumbuhan larva nyamuk. Larva yang mati menunjukan kerusakan pada dinding traktus digestivus. Saponin dapat menurunkan tegangan permukaan selaput 
mukosa traktus digestivus larva, sehingga dinding traktus digestivus menjadi korosif. Saponin dapat menimbulkan busa jika dikocok dalam air dan pada konsentrasi tinggi dapat menyebabkan hemolisis sel darah merah. Saponin memiliki rasa yang pahit sehingga dapat menyebabkan mekanis-me penghambatan makan pada larva uji. Rasa yang pahit menyebabkan larva tidak mau makan sehingga larva akan kelaparan dan akhimya mati.

Penggunaan insektisida kimiawi secara umum sangat berhasil dalam mengendalikan beberapa jenis serangga pengganggu, hama maupun vektor penyebab penyakit seperti nyamuk, namun penggunaan insektisida yang terus menerus akan menyebabkan resistensi bagi serangga dan menimbulkan masalah bagi lingkungan (Gafur et al. 2006). Keracunan pestisida, selain itu juga menimbulkan dampak fatal seperti kanker, cacat tubuh dan kemandulan. Dampak negatif lain diantaranya adalah kematian musuh alami dari mikroorganisme peng-ganggu, kematian organisme yang mengun-tungkan, mengganggu kualitas dan keseim-bangan lingkungan hidup akibat adanya residu serta timbulnya resistensi pada hewan sasaran. Munif (2007), menyatakan bahwa dampak negatif dari penggunaan insektisida kimiawi harus dikurangi. Salah satu alternatif pemberantasan vektor nyamuk adalah dengan cara pengendalian hayati (pengen-dalian biotik).

\section{DAFTAR RUJUKAN}

Anonim2. 2009 . Tanaman Obat Indonesia. http://www.tanaman-obat-indonesia.com [ 20 Desember 2012].

Arikunto, S, 2010, Prosedur Penelitian, Rineka Cipta : Jakarta

Akhsin, 2011., "Parasitologi untuk Keperawatan, Kesehatan Masyarakat, \& Teknik Lingkugan “. Yogyakarta : Nuha Medika.

Chobchuenchum et al., (2004). Tanaman Obat Indonesia. http://www.tanaman-obatindonesia.com [ 25 Desember 2012].

Departemen kesehatan R.I., 2007 Direktorat jederal Pengendalian Penyakit Dan Penyehatan Lingkungan, Bengkulu : DIT. JEN . PP \& PL.

Departemen Pendidikan Nasional. 2005 . Kamus Besar Bahasa Indonesia. Jakarta : Balai Pustaka.
Pemberantasan nyamuk pada stadium larva dilakukan karena pada stadium larva belum bisa menularkan penyakit kepada host sedangkan bila pemberantasan dilakukan pada nyamuk pada stadium nyamuk ini sudah dapat menularkan penyakit kepada host. Bila pemberantasan dilakukan pada stadium larva maka populasi nyamuk akan menurun sehingga penyakit demam berdarah dapat menurun. Pupa tidak terpengaruh oleh saponin karena mempunyai struktur dinding tubuh yang tediri dari kutikula yang keras sehingga senyawa saponin tidak dapat menembus dinding pupa. Bila ada busa positif menunjukkan adanya saponin.

\section{KESIMPULAN}

Disimpulkan bahwa larva yang mati pada berbagai macam dosis larutan akar biduri adalah dosis $32 \mathrm{ml}$ sebanyak 17 ekor dan dosis $38 \mathrm{ml}$ sebanyak 20 ekor, dosis yang paling efektif untuk mematikan larva Aedes aegypti adalah dosis $38 \mathrm{ml}$ dengan konsentrasi larutan sebesar 9.500 ppm serta terdapat perbedaan jumlah larva Aedes aegypti yang mati pada berbagai dosis larutan akar biduri (Calotropis gigantea) yaitu dosis $32 \mathrm{ml}, 34 \mathrm{ml}, 36 \mathrm{ml}$, dan $38 \mathrm{ml}$. Diharapkan dapat melakukan alternatif yang dapat menghilangkan warna dan bau pada larutan yang dihasilkan oleh larutan akar biduri dan bagi masyarakat dapat menggunakan larutan akar biduri ini untuk membuat larvasida alami guna membasmi larva nyamuk Aedes aegypti.

Dinas Kesehatan Kota Bengkulu. 2012. " Profil Kesehatan Kota Bengkulu Tahun 2011”. Bengkulu: Dinkes Kota Bengkulu.

Francis, G., Z Kerem, H.P.S. Makkar and K. Becker. 2007. The Biological action of saponins in animal system : review. British Jurnal Of Nutrition 88: 587 - 605.

Gafur, A., 2006, "Perbedaan jenis Kelamin Aedes aegypti Berdasarkan morfologi sayap”, , Bioscientiae, 3(1) :39-46.

Harian Seputar Indonesia. "Kasus Pemderita DBD di indonesia”. Januari 2013.

Isroi, 2009, "Cara Lebih arif Menangani Damam Berdarah Dengue (DBD), Yogyakarta. www.isroi.file.wordpress/2009/02/various_larva. jpg. 
Kardinan, A., 2007 , "Potensi Selasih Sebagai Repellent Terhaap Nyamuk Aedes aegypti”, Jurnal Litri, 13 (2) : 39

Maoyuan, W., M. Wenli., D. Yuanyuan., L. Shenglan., W. Zhunian and D. Haofu. 2008. Cytotoxic Cardenolide from the Root of Calotropis gigantean. Chinese Academy of Tropical Agricaltural Scienses Danzhou 571737, Hainan, P. R. China. 1(2): 4-9.

Notoatmojo, S., 2010. Metodologi Penelitian Kesehatan. Jakarta: Rineka Cipta.

Noraida, 2000, formula Abbot Corrections, Bandung : ITB

Raina, M.H., 2011. Ensiklopedia Tanaman Obat Untuk Kesehatan, Yogyakarta: Absolut.
Robinson. Trevor, 1995, “Kandungan Organik Tumbuhan Tinggi “, Bandung : ITB

Susanto, A., 2007, "Waspadai Gigitan Nyamuk" Jakarta Selatan : PT Sunda Kelapa Pustaka

Satari, 2008., "Demam Berdarah Perawatan di Rumah \& Rumah Sakit “. Jakarta : Puspa Swara, Anggota IKAPI.

U.S. Enviromental Protection Agency. "Larvasides for Mosquito Control”. U.S. 2007.

Wahana Komunikasi Lintas Spesialis., Oktober 2012 “ Majalah Farmacia “ , Jakarta : PT. SOHO Industri Pharmasi.

World Health Organization, 2005, Dengue Hemorrhagic fever. Diagnosis, treatment, prevention and Control, Mac Milian, New York. 